\title{
Analphoid supernumerary marker chromosome characterized by aCGH and FISH as inv dup(3)(q25.33qter) de novo in a child with dysmorphic features and streaky pigmentation: case report
} Sabita K Murthy*1, Ashok K Malhotra', Preenu S Jacob ${ }^{1}$, Sehba Naveed ${ }^{1}$, Eman EM Al-Rowaished ${ }^{1}$, Sara Mani ${ }^{1}$, Shabeer Padariyakam11, R Pramathan ${ }^{2}$, Ravi Nath ${ }^{2}$, Mahmoud Taleb Al-Ali ${ }^{1}$ and Lihadh Al-Gazali ${ }^{2}$

Address: ${ }^{1}$ Genetics Center, Department of Health and Medical Services, DHA, Dubai, UAE and ${ }^{2}$ Department of Pediatrics, Faculty of Medicine and Health Sciences, Al-Ain Hospital, United Arab Emirates University, Al Ain, UAE

Email: Sabita K Murthy* - skmurthy@dohms.gov.ae; Ashok K Malhotra - malhotra108@yahoo.com; Preenu S Jacob - psjacob@dohms.gov.ae; Sehba Naveed - snaveed@dohma.gov.ae; Eman EM Al-Rowaished - eealrowaished@dohms.gov.ae; Sara Mani - smani@dohms.gov.ae; Shabeer Padariyakam - spmohammed@dohms.gov.ae; R Pramathan - pramathant@uaeu.ac.ae; Ravi Nath - ravinath@emirates.net.ae; Mahmoud Taleb Al-Ali - mtalali@dohms.gov.ae; Lihadh Al-Gazali - algazali@hotmail.com

* Corresponding author

Published: 14 August 2008

Molecular Cytogenetics 2008, I:19 doi:10.1186/1755-8166-1-19
Received: 25 June 2008

Accepted: 14 August 2008

This article is available from: http://www.molecularcytogenetics.org/content///I/I9

(c) 2008 Murthy et al; licensee BioMed Central Ltd.

This is an Open Access article distributed under the terms of the Creative Commons Attribution License (http://creativecommons.org/licenses/by/2.0), which permits unrestricted use, distribution, and reproduction in any medium, provided the original work is properly cited.

\begin{abstract}
Background: Small supernumerary marker chromosomes (sSMC) occur in $0.075 \%$ of unselected prenatal and in $0.044 \%$ of consecutively studied postnatal cases. Individuals with sSMC present with varying phenotype, ranging from normal to extremely mild or severe depending on the chromosomal region involved, the euchromatic content present and degree of mosaicism. Except for chromosomes 15 and 22, the number of reported cases of SSMC is extremely small to provide us with a good genotype-phenotype correlation. Analphoid SSMC are even rarer. To our knowledge only eight cases of analphoid inversion-duplication $3 q$ sSMC are reported so far.

Results: We describe here a one month old female child with several dysmorphic features and with a de novo analphoid supernumerary marker chromosome only in cultured skin fibroblast cells and not in lymphocytes. The marker was characterized as analphoid inversion-duplication 3q25.33qter by oligo array comparative genomic hybridization $(\mathrm{aCGH})$ and fluorescence in situ hybridization (FISH) studies. The final skin fibroblast karyotype was interpreted as 47,XX,+der(3).ish inv dup(3)(qter-q25.33::q25.33-qter)(subtel 3q+,subtel 3q+) de novo.

Conclusion: In addition to the eight reported cases of analphoid inversion-duplication $3 q$ supernumerary marker in the literature, this is yet another case of $3 q \mathrm{sSMC}$ with a new breakpoint at $3 q 25.33$ and with varying phenotype as described in the case report. Identification of more and more similar cases of analphoid inversion-duplication 3q marker will help in establishing a better genotype-phenotype correlation. The study further demonstrates that aCGH in conjunction with routine cytogenetics and FISH is very useful in precisely identifying and characterizing a marker chromosome, and more importantly help in providing with an accurate genetic diagnosis and better counseling to the family.
\end{abstract}




\section{Background}

Small supernumerary marker chromosomes occur in $0.075 \%$ of unselected prenatal cases and in $0.044 \%$ of consecutively studied postnatal cases, and majority of them are de novo in origin [1-4]. Phenotype of individuals with de novo sSMC vary from normal to extremely mild or severe, depending on the chromosomal region involved and the euchromatic content present [5-7]. Although a number of reports describe the occurrence of a variety of sSMC for nearly all the chromosomes, the number for each type is not large enough to suggest a good genotypephenotype correlation for a given $\mathrm{sSMC}$, except for inv $\operatorname{dup}(15)$ and inv $\operatorname{dup}(22)$ where the phenotypic consequences are well described [6,8-10]. We describe here the phenotype and corresponding molecular cytogenetic results of a child with dysmorphic features. This is yet another case of analphoid 3q supernumerary marker chromosome involving a new break point at $3 \mathrm{q} 25.33$. The marker is characterized as inversion-duplication 3q25.33qter by oligo aCGH and FISH studies and it also reveals tissue specific mosaicism.

\section{Case presentation}

A one month old female child presenting with several dysmorphic features was referred to us for cytogenetic studies. She was the second child of unrelated parents. The first child was normal. The pregnancy and delivery at term were normal. Birth weight was $2.2 \mathrm{Kg}$, length $45 \mathrm{~cm}$ and head circumference was $32 \mathrm{~cm}$. At birth she was noted to have several dysmorphic features including: prominent hairy forehead with hair extending up to the cheeks, upslanting palpebral fissures, depressed nasal bridge with short nose and very smooth philtrum, thin upper lip which was turning downward, low set ears, micrognathia, chubby cheeks, contracture of the fingers with postaxial polydactyly of left hand, widely separated toes which were overlapping, streaky pigmentation on the inner aspect of both fore arms distributed along the lines of Blaschko. Opthalmological exam was normal. Echocardiography showed sub-aortic ventricular septal defect (VSD), pulmonary hypertention and moderate valvular pulmonary stenosis. Skeletal survey showed a tiny projection of the tip of coccyx, a tail-like sacrococcygeal appendage. Computed tomography scan of the lumbosacral spine showed prominence of coccyx and outward projection. Magnetic resonance imaging of the brain showed partial hypoplasia of the corpus callosum and slight hypoplasia of the cerebellum.

\section{Results}

Cytogenetic study by Giemsa banding (G-banding) showed normal 46,XX chromosomes in all the 50 lymphocyte cells and $47, X X_{1}+$ mar in all the 70 skin fibroblast cells studied (Fig. 1a). The marker chromosome was constitutive heterochromatin band (C-band) and nucleolar organizer region (NOR) staining negative. Fluorescence in situ hybridization studies using Pan-centromeric alphasatellite FISH probe (Cambio) showed no hybridization onto the marker chromosome (Fig. 1b), confirming it to be analphoid. Immuno-FISH studies for centromere specific proteins could not be undertaken to confirm the formation of a neocentromere. However, the fact that the marker was confirmed as analphoid by FISH and was also found to be highly stable in skin fibroblast culture, strongly suggest of a possible neocentromere formation. Peripheral blood chromosomes of the parents were normal by G-banding and by all chromosome specific subtelomeric FISH analysis. Array-CGH studies on cultured skin fibroblast cells of the patient showed amplification of oligo-probes from probe FLJ14153 at 3q25.33 (160.03 $\mathrm{Mb}$ ) to 3qter (199.29 Mb) (Fig. 2) confirming the origin and breakpoint of the marker chromosome. The observation was further validated by FISH studies using chromosome 3 specific subtelomere FISH probe (Vysis), which revealed the marker to be inversion-duplication 3q25.33qter (Fig. 1c).

\section{Discussion}

Supernumerary marker chromosomes are a cause of great concern and pose huge challenge in routine medical practice, particularly in genetic diagnosis and counseling. Precise identification and complete characterization of the marker chromosome is very important to understand the underlying cause of the disease and to establish a good genotype-phenotype correlation.

Analphoid markers are rare observations, in which the marker chromosome lacks centromeric alphoid DNA sequences, that are otherwise typically present in normal functional centromeres. Survival and stability of such an analhpoid marker chromosome depends on the formation of a neocentromere [11]. At present 73 cases of neocentromeric sSMC originating from different chromosomes are reported in the literature, of which 13q, $15 q$ and $3 q$ are the most frequent observations [1]. To our knowledge only 9 cases of analphoid 3q inversion-duplication marker (including the present case) are reported so far, involving chromosomal break points 3q22.3, 3q25.33, 3q26.2, 3q27.1, 3q27.2 and 3q28 [12-19]. A brief summary of the clinical features, chromosomal breakpoints and degree of mosaicism of the reported cases with $3 q$ inversion-duplication supernumerary marker chromosome is presented in Table 1. As can be seen, the most frequent break point is at 3q26.2 (4 out of 9 cases) suggesting that this is possibly the most common site of neocentromere formation in a $3 \mathrm{q}$ marker. However, findings of other break points between 3q22 to 3q28 strongly suggest that this region probably has several potential hotspots of necentromere formation. 


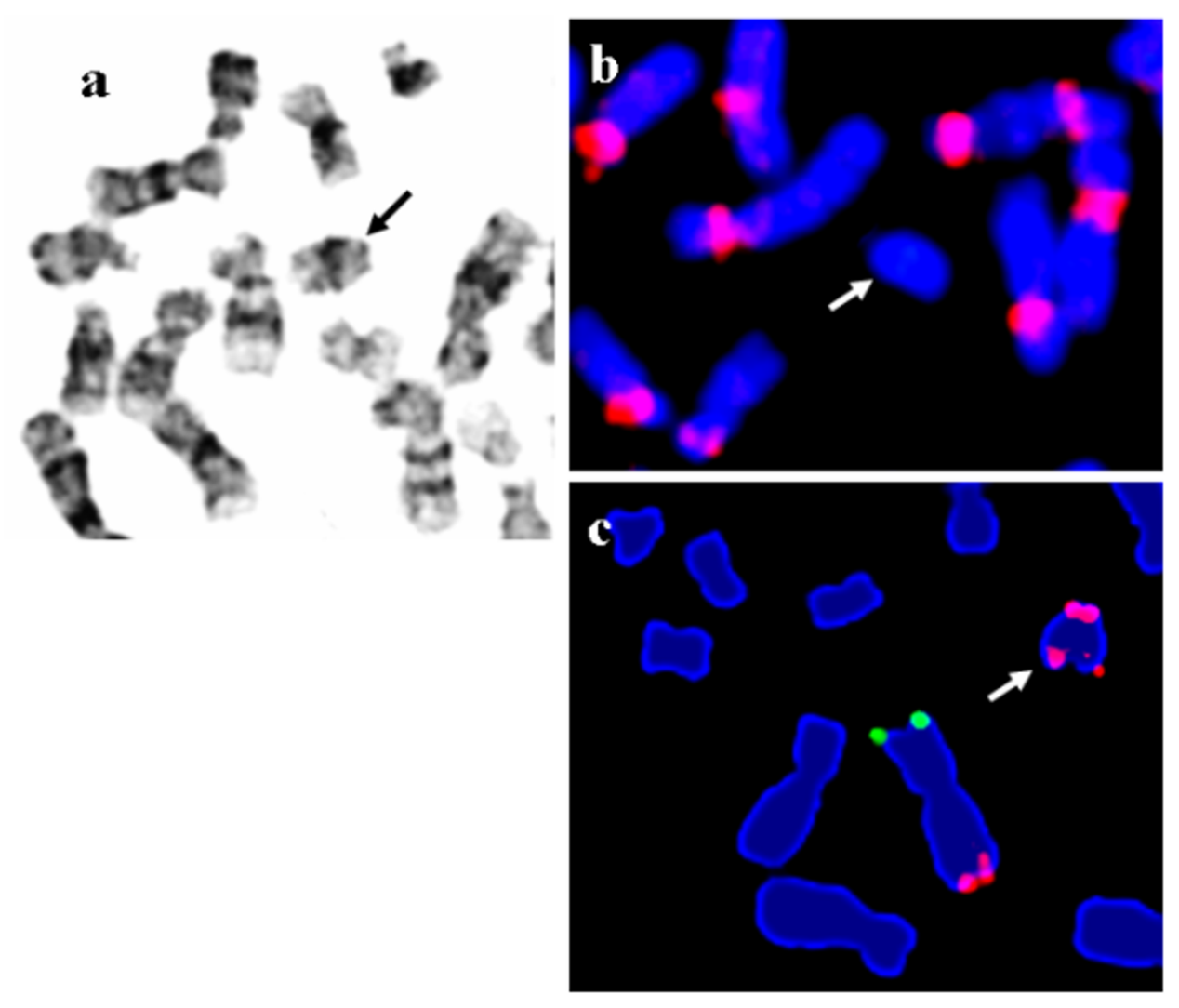

\section{Figure I}

a) Partial G-banded metaphase from skin fibroblast cell showing the marker chromosome (arrow). b) Supernumerary marker chromosome showing no hybridization with human alpha-satellite Pan-centromeric probe (Cambio). (c) Chromosome 3 specific subtelomeric FISH (Mix 3 - Vysis) showing one normal chromosome 3 (3ptel green/3qtel red) and the marker chromosome with two red signals for $3 q$ subtelomere, confirming the marker to be inversion-duplication 3q25.33-qter.

Although all of the above cases with an analphoid $3 q$ marker chromosome share some common clinical features, they still show widely varying phenotypes, probably due to the presence of varying euchromatic content as well as varying degree of mosiaicism (Table 1). Except for the case described by Portnoi et al [17] where the patient presented only with lines of Blaschko but otherwise healthy and not dysmorphic, all the other reported cases presented with developmental delay, severe dysmorphic features and multiple congenital anomalies involving several organs and systems. Our present case with break point at 3 q25.33 presented with strikingly distinct phenotype as described in the case report. The typical facial appearance and the prominent hairy forehead are distinctive features, in addition to the cardiac and skeletal abnormalities that are similar to the cases described by Gimelli et al and Cockwell et al[12,13].

Mosaicism is reported in 59\% of cases where the sSMC are found in association with a normal cell line [4]. Five of the nine cases discussed here showed tissue specific mosaicism where the $3 \mathrm{q}$ marker was present only in fibroblasts and not in lymphocytes (case number 1-3 and 5-6 of Table 1), other two cases showed varying degree of mosaicism in lymphocytes as well as in fibroblasts (case number 4 and 7 of Table 1), and the remaining two cases had the marker chromosome in $71 \%$ and $100 \%$ lymphocytes respectively (case number 8 and 9 of Table 1). Keeping in mind the specific clinical features of the patient and with the application of modern molecular cytogenetic detection methods such as aCGH and FISH, more and more similar cases are likely to be identified that would further help in obtaining a better genotypephenotype correlation, and in providing with an accurate genetic diagnosis and better informed counseling, which is highly valuable to the patients. 

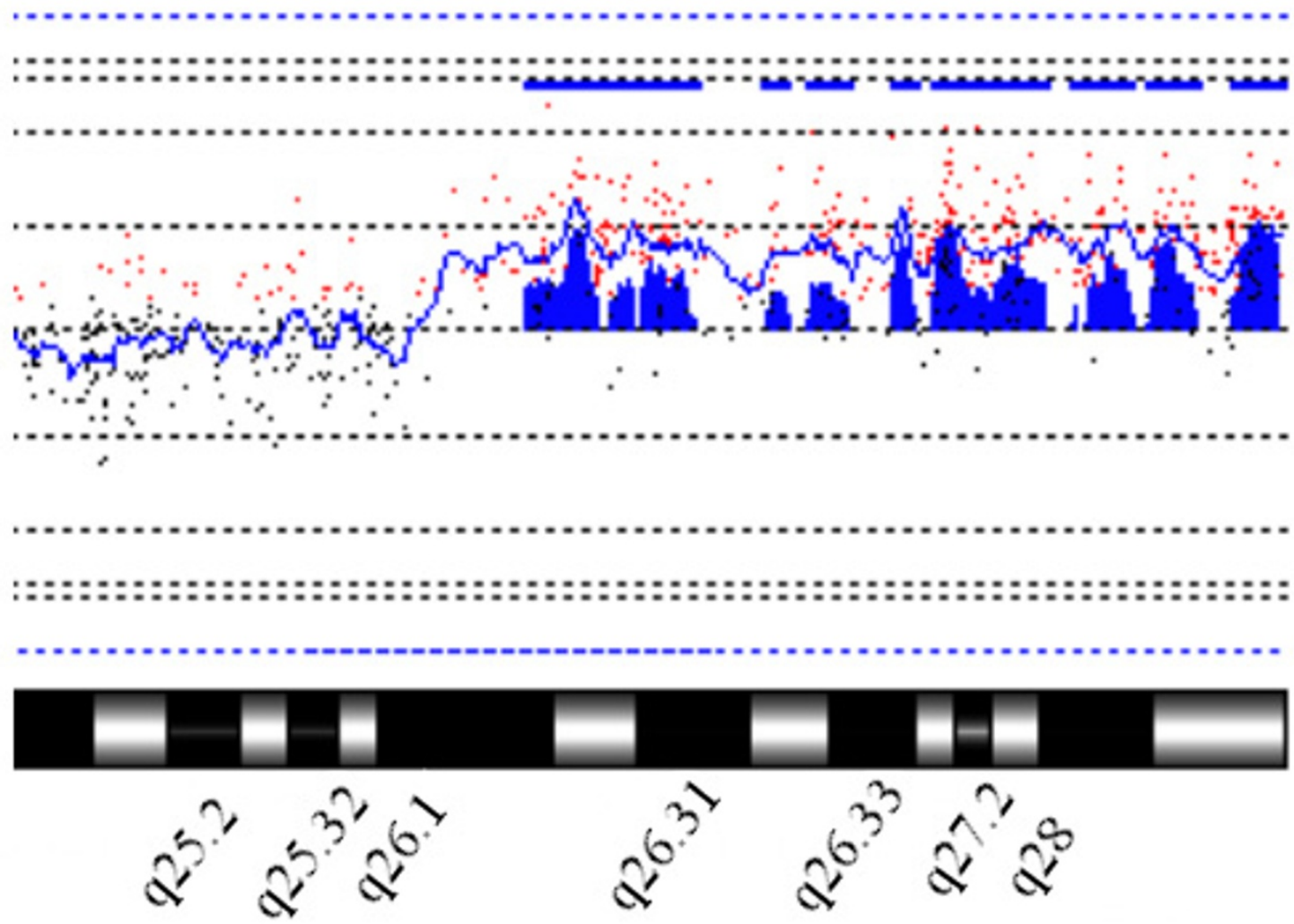

\section{Figure 2}

Oligo aCGH study using Agilent $44 \mathrm{~K}$ oligo array. Labeling and hybridization are as described in methods. Figure shows a partial cytogenetic profile of chromosome $3 q$ and amplification of chromosomal region 3q25.33-qter.

\section{Methods}

\section{Cytogenetic and fish studies}

Cytogenetic study was carried out on peripheral blood lymphocytes by G-banding according to the standard procedures [20], and 50 G-banded metaphases were analyzed. FISH study was undertaken using all chromosome specific sub-telomere FISH probes (Vysis). Hybridization and washing was done as per manufacturer's protocol and 100 metaphases were analyzed. Due to the strong abnormal clinical presentation and presence of prominent streaky pigmentation, further studies were undertaken on cultured skin fibroblast cells by routine G-banding and 70 metaphase spreads were analyzed, followed by C-band and NOR staining [20]. To further characterize the marker chromosome, alpha-satellite Pan-centromeric (Cambio) and chromosome 3 specific sub-telomeric (Vysis) FISH studies were performed as per manufacturer's instructions.

\section{Oligo array CGH studies and validation}

Oligo aCGH analysis was carried out using Human 44A microarray (Agilent) to determine the origin of the marker chromosome and to precisely identify the breakpoint region involved in the formation of the marker. The array contained in situ synthesized 60-mer oligonucleotides representing a total of 44,290 features. The oligonucleotide probes span the human genome with an average spatial resolution of approximately $\sim 75 \mathrm{~Kb}$, including coding and non-coding sequences, providing sufficient coverage for a genome-wide survey of DNA aberrations. Genomic DNA was extracted from cultured skin fibroblast cells of the patient by routine Proteinase $\mathrm{K}$ method and co-hybridized with normal male control DNA (Promega). DNA labelling, hybridization to oligonucleotide-array and post washing was carried out according to the protocol from Agilent Technologies and as described in Murthy et al [21]. Array CGH result was further validated by FISH study using chromosome 3 specific subtelomere FISH probe (Vysis).

\section{Competing interests}

The authors declare that they have no competing interests. 
Table I: Karyotype and clinical presentation of individuals reported with a supernumerary analphoid inversion-duplication $3 q$ marker chromosome

\begin{tabular}{|c|c|c|c|}
\hline Case no. & Karyotype & Clinical features & References \\
\hline I & $\begin{array}{l}\text { 47,XY,+der(3) inv dup(3)(qter-q22.3::q22.3-qter) in } \\
\text { dark skin fibroblast only (87\%) 46,XY (in PBL \& light skin) }\end{array}$ & $\begin{array}{l}\text { Lumbosacral maningeocele, mental retardation, sparse hair, } \\
\text { short limbs, hypoplasia of digital phalanges, agensis of nails } \\
\text { and clinodactyly of fifth finger, ambiguous genitalia, } \\
\text { depressed nasal bridge, anteverted nostrils lines of } \\
\text { Blaschko, severe developmental delay. }\end{array}$ & {$[12,19]$} \\
\hline 2 & $\begin{array}{l}\text { 47,XX,+der(3) inv dup(3)(qter-q25.33::q25.33-qter) in } \\
\text { skin fibroblast only (100\%) 46,XX (PBL) }\end{array}$ & $\begin{array}{l}\text { Multiple congenital anomalies, prominent hairy forehead, } \\
\text { low set ears, micrognathia, postaxial polydactyly of left } \\
\text { hand, depressed nasal bridge, short nose, lines of Blaschko, } \\
\text { sub arortic VSD, pulmonary hypertension, tail-like } \\
\text { sacrococcygeal appendage, hypoplasia of corpus callosum. }\end{array}$ & present case \\
\hline 3 & $\begin{array}{l}\text { 47,XY,+der(3) inv dup(3)(qter-q26.2::q26.2-qter) in } \\
\text { skin fibroblast (57\%) }\end{array}$ & $\begin{array}{l}\text { Abortus with high arched palate, postnuchal edema, single } \\
\text { transverse palmer crease on rt. hand lumbosacral } \\
\text { myelomengiocele, Arnold-Chiari malformation, asymmetry } \\
\text { of the kidneys, renal dysplasia. }\end{array}$ & {$[13,19]$} \\
\hline 4 & $\begin{array}{l}\text { 47,XY,+der(3) inv dup(3)(qter-q26.2::q26.2-qter) in } \\
\text { skin fibroblast (88\%) in PBL ( } 2.5 \%)\end{array}$ & $\begin{array}{l}\text { Enlargerd kidney, streaky hypopigmentation of skin, wide } \\
\text { open anterior and posterior fontanel, rt preauricular pit, } \\
\text { accessory nipples, postaxial polydactyly, clinodactyly of } 5^{\text {th }} \\
\text { finger, rocker bottom feet, seizures, duplication of rt } \\
\text { kidney, right pulmonary srtery stenosis, developmental } \\
\text { delay. }\end{array}$ & {$[14,19]$} \\
\hline 5 & $\begin{array}{l}47, X Y,+\operatorname{der}(3) \text { inv dup(3)(qter-q26.2::q26.2-qter) in } \\
\text { skin fibroblast } 46, X Y(P B L)\end{array}$ & $\begin{array}{l}\text { Mild developmental delay, attention-deficit hyperactivity, } \\
\text { asymmetry of hands and legs, lines of irregular skin } \\
\text { pigmentation consistent with the lines of Blaschko, } \\
\text { macrocephaly. }\end{array}$ & {$[15,19]$} \\
\hline 6 & $\begin{array}{l}47, X X,+\operatorname{der}(3) \text { inv dup(3)(qter-q26.2::q26.2-qter) in } \\
\text { skin fibroblast (24\%) } 46, X X(P B L)\end{array}$ & $\begin{array}{l}\text { Skeletal abnormalities, limb stiffness, abnormal skin } \\
\text { pigmentation, developmental delay. }\end{array}$ & {$[16,19]$} \\
\hline 7 & $\begin{array}{l}\text { 47,XY,+der(3) inv dup(3)(qter-q27.1::q27. I-qter) in } \\
\text { dark skin fibroblast } \\
(6 \%) \text { in } P B L(30 \%) 46, X Y(100 \% \text { in light skin) }\end{array}$ & $\begin{array}{l}22 \text { year old man, normal intelligence, onset of pigmentary } \\
\text { anomalies at age } 10-12 \text { years, lines of Blaschko, otherwise } \\
\text { healthy and not dysmorphic. }\end{array}$ & {$[17,19]$} \\
\hline 8 & $\begin{array}{l}47, X X,+\operatorname{der}(3) \text { inv dup(3)(qter-q27.2::q27.2-qter) in } \\
P B L(7 \mid \%)\end{array}$ & $\begin{array}{l}\text { Swirly areas of hyperpigmentation, bilateral preauricular } \\
\text { pits, hypotonia, developmental delay, seizures. }\end{array}$ & {$[14,19]$} \\
\hline 9 & $\begin{array}{l}47, X X,+\operatorname{der}(3) \text { inv dup(3)(qter-q28::q28-qter) } \\
(100 \% \text { in PBL) }\end{array}$ & $\begin{array}{l}\text { Marked developmental delay, Hypognathia, atypical } \\
\text { epicanthus, slight hirsutism, bilateral icthyosiform } \\
\text { hyperkerotosis of palms and sole, hypotonia, hyporeflexia, } \\
\text { cannot speak properly. }\end{array}$ & {$[18,19]$} \\
\hline
\end{tabular}

(PBL = peripheral blood lymphocyte culture)

\section{Authors' contributions}

SKM conceived the study and drafted the manuscript. LG referred the patient, and RN and LG contributed clinical information. AKM, EEMR, SM, RP performed banding and cytogenetic analysis; SN and SP did FISH and PSJ did aCGH studies. MTA provided valuable support. All authors read and approved the final manuscript.

\section{Consent}

This case report is presented with the consent of the patient's family.

\section{Acknowledgements}

We acknowledge the Department of Health and Medical Services (DOHMS), Dubai and Center for Arab Genomic studies (CAGS), Dubai for supporting the work.

\section{References}

I. Liehr T, Utine GE, Trautmann U, Rauch A, Kuechler A, Pietracz J, Bocian E, Kosyakova N, Mrasek K, Broduroglu K, Weise A, Aktas D:
Neocentromeris small supernumerary marker chromosomes (sSMC) - three more cases and review of literature. Cytogenet Genome Res 2007, I I 8:3 I-37.

2. Buckton KE, Spowart G, Newton MS, Evans HJ: Fortyfour probands with an additional 'marker' chromosome. Hum Genet 1985, 69:353-370.

3. Crolla JA: FISH and molecular studies of autosomal supernumerary marker chromosomes excluding those derived from chromosome I 5. II. A review of literature. Am J Med Genet 1998, 75:367-38I.

4. Crolla JA, Youings SA, Ennis S, Jacobs PA: Supernumeray marker chromosomes in man: parental origin, mosaicism and maternal age revisited. Eur J Hum Genet 2005, I 3: I 54- I60.

5. Liehr T, Mrasek K, Weise A, Dufke A, Rodriguez L, Martinez Guardia N, Sanchis A, Vermeesch JR, Ramel C, Polityko A, Haas OA, Anderson J, Claussen U, von Eggeling F, Starke H: Small supernumerary marker chromosomes: progress towards a genotype-phenotype correlation. Cytogenet Genome Res 2006, I I 2:23-34.

6. Dennis NR, Veltman MW, Thompson R, Craig E, Bolton PF, Thomas NS: Clinical findings in 33 subjects with large supernumerary marker( 15$)$ chromosomes and 3 subjects with triplication of I 5q I I-q I3. Am J Med Genet 2006, I 40(5):434-44 I.

7. Starke H, Nietzel A, Weise A, Heller A, Mrasek K, Belitz B, Kelbova C, Volleth M, Albrecht B, Mitulla B, Trappe R, Bartels I, Adolph S, Dufke A, Singer S, Stumm M, Wegner RD, Seidel J, Schmidt A, Kuechler A, Schreyer I, Claussen U, von Eggeling F, Liehr T: Small super- 
numerary marker chromosomes (SMCs): genotypephenotype correlation and classification. Hum Genet 2003, I | 4(I):5 I-67.

8. Crolla JA, Harvey JF, Sitch FL, Dennis NR: Supernumerary marker I 5 chromosomes: a clinical, molecular and FISH approach to diagnosis and prognosis. Hum Genet 1995, 95:16 I-70.

9. Crolla JA, Howard P, Mitchell C, Long FL, Dennis NR: Am J Med Genet 1997, 72:440-7.

10. Warburton D: De novo balanced chromosome rearrangements and extra marker chromosomes identified at prenatal diagnosis: clinical significance and distribution of breakpoints. Am J Hum Genet I991, 49:995-1013.

II. Choo KHA: Centromere DNA dynamics: latent centromeres and neocentromere formation. Am J Hum Genet 1997 , 6 I:1225-33.

12. Gimelli G, Giorda R, Beri S, Gimelli S, Zuffardi O: A large analphoid inv dup(3q22.3) marker chromosome characterized by array-CGH in a child with malformations, mental retardation, ambiguous genitalia and Blaschko's lines. Eur J Med Genet 2007, 50(4):264-273.

13. Cockwell A, Gibbons B, Moore I, Crolla JA: An analphoid supernumerary marker chromosome derived from chromosome 3 ascertained in a fetus with multiple malformations. J Med Genet 2000, 37:807-809.

14. Teshima T, Bawle M, Weksberg R, Shuman C, Van Dyke DL, Schwartz S: Analphoid 3qter markers. Am J Med Genet 2000, 94(2): II3-119.

15. Yu J, Qi Z, Thompson K, Modaff P, Wells W, Meisner L, Pauli R: Characterization of a rare neocentric marker chromosome using chromosome microdissection. 54th annual meeting of the American Society of Human Genetics 2004:192.

16. Sullivan CM, Mountford ST, Emmerson JM, Ellis RJ, Turmbull C Waters KS: A mosaic karyotype with an additional inv dup(3)(qter-q26.2::q26.2-qter), containing a neocentromere, detected in a skin biopsy from a girl with skeletal abnormalities, abnormal skin pigmentation and developmental delay. J Med Genet 2005, 42(Suppl I):S7I. (Abstract \# 2.23)

17. Portnoi MF, Boutchnei S, Bouscarat F, Morlier G, Nizard S, Dersarkissian H, Crickx B, Nouchy M, Taillemite JL, Belaich S: Skin pigmentary anomalies and mosaicism for an acentric marker chromosome originating from 3q. I Med Genet 1999 36:246-250

18. Barbi G, Spaich C, Adolph S, Kehrer-Sawatzki H: Analphoid de novo marker chromosome inv dup(3)(q28qter) with neocentromere in a dysmorphic and developmentally retarded girl. J Med Genet 2003, 40(3):e27.

19. Liehr T: Small supernumerary marker chromosome (sSMC). [http://www.med.uni-jena.de/fish/sSMC/03.htm].

20. Rooney DE: Chromosome staining and banding techniques. In Human Cytogenetics: constitutional analysis. A practical approach Edited by: Rooney DE. Oxford university press; $200 \mathrm{I}$.

21. Murthy SK, Nygren AOH, El Shankiry HM, Schouten JP, Al Khayat AI, Ridha A, Al Ali MT: Detection of a novel familial deletion of four genes between BPI and BP2 of the Prader-Willi/Angelman syndrome critical region by oligo-array $\mathrm{CGH}$ in a child with neurological disorder and speech impairment. Cytogenet Genome Res 2007, I | 6: | 35-140.
Publish with Biomed Central and every scientist can read your work free of charge

"BioMed Central will be the most significant development for disseminating the results of biomedical research in our lifetime. "

Sir Paul Nurse, Cancer Research UK

Your research papers will be:

- available free of charge to the entire biomedical community

- peer reviewed and published immediately upon acceptance

- cited in PubMed and archived on PubMed Central

- yours - you keep the copyright
BioMedcentral 